\title{
Pengaruh Penerapan Supply Chain Management Coffee Shop Kota Bandung Bagian Selatan terhadap Competitive Advantage
}

\author{
Wiji Safitri $^{1}$, Ratih Hendayani ${ }^{2}$, Ruben Shosa Shobura ${ }^{3}$ \\ ${ }^{1}$ Universitas Pelita Bangsa \\ e-mail:wijisafitri@pelitabangsa.ac.id \\ ${ }^{2,3}$ Universitas Telkom \\ e-mail: ${ }^{2}$ ratihendayani@gmail.com, ${ }^{3}$ shosashobura@gmail.com

\begin{tabular}{ccc} 
Diterima & Direvisi & Disetujui \\
$18-02-2020$ & $29-02-2020$ & $02-03-2020$ \\
\hline
\end{tabular}

\begin{abstract}
Abstrak - Industri Makanan dan minuman di Indonesia tumbuh pesat. Sebagai negara penghasil kopi terbesar keempat di dunia dan potensi pasar pengolahan kopi yang terus tumbuh, Industri perlu menerapkan Supply Chain Management untuk keunggulan bersaing. Tujuan dari penelitian ini adalah untuk mengetahui bagaimana pengaruh Supply Chain Management terhadap Compettitive Advantage di lima Kedai Coffee Shop di Kota Bandung Bagian Selatan. Penelitian ini menggunakan metode penelitian kuantitatif dan eksplanatori dengan pendekatan causal. Variabel bebas dalam penelitian ini adalah Supply Chain Management yang terdiri dari Infrastructure Framework, Delivery Dependability, Time to Market, dan Supply Chain Agility sementara variabel terikat adalah Competitive Advantages terdiri dari Manufacturing Firm Performance. Populasi dalam penelitian ini adalah Owner, Manajer Logistik, Manajer Penjualan, Manajer Keuangan dan Barista di 5 Coffee Shop Kota Bandung Bagian Selatan. Sementara sampel menggunakan sampel jenuh dengan jumlah 30 orang. Teknik analisis data menggunakan Multivariate Analysis yaitu Teknik dependent, Teknik interdependent, dan Teknik persamaan structural (structural model). Hasil dari penelitian adalah Infrastructure Framework ke Delivery Dependability terhadap Competitive Advantage mempunyai pengaruh signifikan positif, Infrastructure Framework ke Time to Market mempunyai pengaruh signifikan positif terhadap Competitive Advantage, Delivery Dependability ke Supply Chain Agility mempunyai pengaruh signifikan positif terhadap Competitive Advantage, Supply Chain Agility mempunyai pengaruh signifikan positif terhadap Competitive Advantage. Dengan ini, Coffee Shop perlu mempertimbangkan faktor tersebut untuk meningkatkan keunggulan bersaing dalam bisnis.
\end{abstract}

Kata Kunci: Coffee Shop, Competitive Advantage, dan Supply Chain Management

\begin{abstract}
Industry food and beverage in Indonesia is growing rapidly. As the fourth largest coffee producing in the world and as has potential processing coffee market, the Industry business needs to implement Supply Chain Management for competitive advantage. The research aims to find how Supply Chain Management influences Competitive Advantage in the five Southern Bandung City Coffee Shop. The present study uses quantitative and explanatory research methods with a descriptive approach. The independent variable in this study is Supply Chain Management which consists of Infrastructure Framework, Delivery Dependability, Time to Market, and Supply Chain Agility while the dependent variable is Competitive Advantages consisting of Manufacturing Firm Performance. The populations in this study are the Owner, Logistics Manager, Sales Manager, Financial Manager and Barista at the Southern Bandung City Coffee Shop. While the sample uses a saturated sample of 30 people. Data analysis techniques using Multivariate Analysis, namely dependent technique, interdependent technique, and structural equation technique (structural model). The results of the study are Infrastructure Framework to Delivery Dependability on Competitive Advantage has a significant positive effect, Infrastructure Framework to Time to Market has a significant positive effect on Competitive Advantage, Delivery Dependability to Supply Chain Agility has a significant positive effect on Competitive Advantage, Supply Chain Agility has a significant positive effect on Competitive Advantage. With this, Coffee Shop needs to consider these factors to increase competitive advantage in business.
\end{abstract}

Keywords : Coffee Shop, Competitive Advantage, and Supply Chain Management

\section{PENDAHULUAN}

Industri makanan dan minuman menjadi salah satu sektor manufaktur andalan dalam memberikan kontribusi besar terhadap pertumbuhan ekonomi nasional. Capaian kinerjanya selama ini tercatat konsisten terus positif, mulai dari perannya terhadap peningkatan produktivitas, investasi, ekspor hingga 
penyerapan tenaga kerja. Menurut Mentri Perindustrian Airlangga Hartono mencatat, sepanjang tahun 2018, industri makanan dan minuman mampu tumbuh sebesar 7,91 persen atau melampaui pertumbuhan ekonomi nasional di angka 5,17 persen. Bahkan, pertumbuhan produksi industri manufaktur besar dan sedang di triwulan IV-2018 naik sebesar 3,90 persen ( $y$-on-y) terhadap triwulan IV-2017, salah satunya disebabkan oleh meningkatnya produksi industri minuman yang mencapai 23,44 persen (Kementrian Perindustrian Republik Indonesia, 2019).

Pertumbuhan usaha kedai kopi hingga akhir 2019 diprediksi mencapai 15\%-20\%, naik jika dibandingkan dengan 2018 yang hanya mencapai 8\%-10\%. Chairman Specialty Coffee Association of Indonesia (SCAI), Syafrudin mengatakan, saat ini kontribusi kedai kopi terhadap serapan kopi produksi dalam negeri mencapai $25 \%-30 \%$. Angka tersebut diprediksi terus naik ke level 35\%-40\% pada akhir tahun 2019 (Zuhriyah, 2019).

Fenomena meningkatnya pertumbuhan coffee shop di Kota Bandung mengakibatkan kompetisi persaingan dalam industri coffee shop semakin ketat. Salah satunya di daerah Selatan Kota Bandung yang meliputi daerah Buahbatu, Lengkong, Turangga, Batununggal, dan sekitarnya. Selain itu banyaknya Universitas dan Sekolah Tinggi lainnya yang berada di daerah Kota Bandung bagian Selatan juga merupakan faktor pendukung menjamurnya kedai Coffee Shop. Serta ada sumber dari Badan Pusat Statistik Kota Bandung tahun 2018 yang di dapat dari hasil penelitian (Oseptharia, 2018).

Tabel 1. Jumlah Usaha Kafe dan Coffee Shop di Bandung Tahun 2012-2017

\begin{tabular}{|l|l|l|}
\hline Tahun & $\begin{array}{c}\text { Jumlah Kafe dan } \\
\text { Coffee Shop }\end{array}$ & Pertumbuhan \\
\hline 2012 & 196 & - \\
\hline 2013 & 235 & $19,90 \%$ \\
\hline 2014 & 432 & $83,80 \%$ \\
\hline 2015 & 653 & $51,15 \%$ \\
\hline 2016 & 795 & $21,74 \%$ \\
\hline 2017 & 870 & $9,43 \%$ \\
\hline
\end{tabular}

Sumber: (Oseptharia, 2018).

Dari tabel 1 dapat dinyatakan bahwa jumlah kafe dan coffee shop di Kota Bandung dari tahun 2012 sampai tahun 2017 terus meningkat dan hal itu dapat memicu persaingan antar kafe dan coffee shop di Kota Bandung.

Dari persebaran wilayah di Kota Bandung, penulis memilih wilayah Kota Bandung bagian Selatan meliputi berbagai kecamatan, antaranya Kecamatan Bandung Kidul dan Kecamatan Lengkong lantaran terdapat banyaknya perguruan tinggi dan universitas di daerah tersebut. Jumlah perguruan tinggi di Bandung Kidul dan Kecamatan Lengkong berdasarkan tracking Google Maps adalah 22 Perguruan Tinggi (GoogleMaps, 2019). Selain itu, di wilayah tersebut terdapat 5 kedai coffee shop yang digemari masyarakat Kota Bandung bagian Selatan yaitu 911 Coffee Lab, Monelab, Teorema Coffee, Suarasa Coffee, dan Bicara Street Coffee.

Meningkatnya pertumbuhan coffee shop di bagian selatan kota Bandung mengakibat kompetisi persaingan dalam industri coffee shop semakin ketat. Didorong dengan penerapan Supply Chain yang mereka terapkan untuk memperoleh keunggulan bersaing dengan kompetitor lainnya. Data 5 kedai coffee shop di Kota Bandung Bagian selatan yang digemari masyarakat seperti pada tabel 2 berikut ini:

Tabel 2. Supplier Coffee Shop

\begin{tabular}{|l|l|l|}
\hline No & $\begin{array}{c}\text { Nama Coffee } \\
\text { Shop }\end{array}$ & \multicolumn{1}{c|}{ Supplier } \\
\hline 1 & $911 \quad$ Coffee & $\begin{array}{l}\text { - Genetic Coffee (Puntang } \\
\text { Natural Speciality Coffee) } \\
-911 \text { Coffee Roastery } \\
- \text { Space Coffee \& Roastery }\end{array}$ \\
\hline 2 & Monelab & $\begin{array}{l}\text { - Nitro Coffee } \\
\text { - Genesis Coffee } \\
\text { - Coday Coffee Lab \& Roastery }\end{array}$ \\
\hline 3 & $\begin{array}{l}\text { Teorema } \\
\text { Coffee }\end{array}$ & $\begin{array}{l}\text { - The Journey } \\
\text { - Javanica Roastery } \\
\text { - Kopi Dewa }\end{array}$ \\
\hline 4 & $\begin{array}{l}\text { Suarasa } \\
\text { Coffee }\end{array}$ & $\begin{array}{l}\text { - Space Coffee Roastery } \\
\text { - Bean House Coffee Roaster } \\
\text { - Herd Coffee Roaster }\end{array}$ \\
\hline 5 & $\begin{array}{l}\text { Bicara Street } \\
\text { Coffee }\end{array}$ & $\begin{array}{l}\text { - Coffee Smith } \\
\text { - Caffeetto Coffee } \\
\text { - Makmur Jaya Coffee Roastery }\end{array}$ \\
\hline
\end{tabular}

Sumber: Olahan Penulis, 2019

Dari Tabel 2 terlihat bahwa beberapa kedai Coffee Shop memiliki supplier yang berbeda-beda, hal ini menjadi masalah yang serius bagi owner di setiap kedai untuk persaingan antar kompetitor dan meraih hati para konsumen. Dalam hal ini berbagai kedai Coffee Shop mulai menerapkan sistem Supply Chain untuk memperoleh Keunggulan dalam bersaing (Competitive Advantage). Kedai Coffee Shop harus memperhatikan beberapa faktor, seperti Infrastructure Framework, Delivery Dependability, Time to Market, dan Supply Chain Agility, untuk mencapai performa yang maksimal dan memperoleh keunggulan dalam bersaing.

\section{Supply Chain Management}

Supply Chain Management (SCM) adalah serangkaian kegiatan yang meliputi koordinasi, penjadwalan, dan pengendalian terhadap pengadaan, produksi, persediaan dan pengiriman produk ataupun layanan jasa kepada pelanggan yang mencakup administrasi harian, operasi, logistik dan pengolahan informasi mulai dari customer hingga supplier. Untuk penjelasan singkatnya Supply Chain Management 
(SCM) adalah mekanisme yang menghubungkan semua pihak yang bersangkutan dan proses berubahnya bahan baku menjadi sebuah produk. Pihak yang ikut serta adalah yang bertanggung jawab untuk memberikan barang - barang jadi hasil produksi ke customer pada waktu dan tempat yang tepat dengan cara yang paling efisien (Pangestu, 2016).

Dalam prosesnya, strategi supply chain management memilik tiga tujuan. Tujuan penerapan supply chain management yang pertama adalah cost reduction, supply chain management yang dijalankan perusahaan harus dapat meminimalkan biaya logistik yang terjadi, misalnya dengan memilih alat/model transportasi, penggudangan, standar, dan layanan yang meminimalkan biaya. Kedua, supply chain management bertujuan untuk capital reduction yang ditujukan untuk meminimalisasikan tingkat investasi dalam strategi logistik. Strategi ini dapat menghasilkan biaya variabel yang lebih tinggi dari pada strategi yang membutuhkan level yang lebih tinggi untuk investasi, tetapi pada saat pengembalian investasi diharapkan dapat meningkat. Ketiga, penerapan supply chain management diharapkan dapat memperbaiki pelayanan secara terus menerus (service improvement) (Siagian, 2005:22-23) dalam (Wulandari, Sari, \& L, 2016).

\section{Agility Supply Chain}

Supply chain agility (SCA) adalah kemampuan yang dimiliki untuk dapat melakukan proses rantai pasokan yang fleksibel, yaitu kompetensi dalam organisasi internal. Namun, kelincahan dan fleksibilitas adalah dua konsep yang berbeda dan belum terkait satu sama lain, dan kelincahan adalah awal dari fleksibilitas (Eshlaghy, 2014) dalam (Aisy, 2019). Rantai pasokan yang tangkas dapat beradaptasi dengan perubahan, ketidakpastian yang tidak dapat diprediksi dalam lingkungan bisnis dan menciptakan respons yang tepat untuk berubah. Oleh karena itu, rantai pasokan membutuhkan kemampuan untuk menanggapi perubahan (Aisy, 2019).

Banomyong (2007) dalam (Al-Shboul, 2017) memunjukan bahwa kinerja rantai pasok perlu diukur berdasarkan tiga dimensi, yaitu biaya, waktu dan kendala, karena dimensi ini mencerminkan output dari operasi Supply Chain serta kemampuan untuk memenuhi kebutuhan pelanggan dengan biaya terendah, seperti sebeberapa cepat mungkin dan ketepatan waktu yang dicapai.

\section{Time to Market}

Dalam penanganan produk-produk inovatif, kecepatan meluncurkan rancangan-rancangan baru sangatlah penting. Time to Market sendiri adalah waktu antara gagasan perancangan produk di mulai sampai produk tersebut dipasarkan, Proses dari pencarian ide sampai rancangan siap diluncurkan bisa cukup lama dan seringkali terjadi pengulangan- pengulangan untuk menyesuaikan rancangan dengan informasi-informasi terbaru yang diperoleh ti perancan. Dalam rangka mengurangi pengulanganpengulangan yang mahal dan lama, berbagai aktivitas yang terkait dengan perancangan dan peluncuran produk baru dikerjakan lebih dini, misalnya perancangan proses manufaktur sudah dimulai sebelum rancangan produk selesai dibuat (Achlaq, 2015)

\section{Delivery Dependability}

Target kinerja yang ditetapkan oleh perusahaan akan memotivasi personel untuk mencapai target tersebut. Target yang ditetapkan akan menjadi ukuran berhasil atau tidaknya perusahaan dan setiap anggota perusahaan dalam menjalankan kegiatan operasional. Kinerja yang baik akan berdampak pada keberlangsungan hidup perusahaan. Untuk tercapainya kinerja yang baik, maka diperlukan adanya penilaian kinerja. Kinerja perusahaan dapat ditingkatkan dengan keunggulan bersaing perusahaan. Dengan terpenuhinya indikator keunggulan perusahaan seperti harga, kualitas, delivery dependability, inovasi produk, dan time to market, tingkat penjualan perusahaan akan meningkat. Selain itu, kepuasan dan loyalitas konsumen juga akan meningkat yang kemudian akan berimbas pada meningkatnya kinerja perusahaan baik keuangan maupun non keuangan. Kepuasan pelanggan, kualitas bahan baku dari supplier, dan distribusi produk dengan waktu yang tepat seakan menjadi kunci keunggulan bersaing dalam supply chain management. (Wulandari, Sari, \& L, 2016).

\section{Competitive Advantage}

Keunggulan kompetitif atau Competitive Advantage adalah sesuatu yang memungkinkan perusahaan untuk memperoleh laba lebih tinggi dari pada laba rata-rata (Ifle, 2017).

Keunggulan kompetitif sendiri merupakan manfaat atau nilai yang diciptakan oleh Perusahaan untuk pembeli melebihi biaya yang dikeluarkan perusahaan (Suharto \& Devie, 2013)

Kinerja atau performance sering diartikan sebagai hasil kerja atau prestasi kerja. Kinerja mempunyai makna yang lebih luas, bukan hanya menyatakan hasil kerja, tetapi juga bagaimana proses kerja berlangsung. Kinerja adalah tentang melakukan pekerjaaan dan hasi (Alhamid \& Anufia, 2019)1 yang dicapai dari pekerjaan tersebut. Kinerja adalah tentang apa yang dikerjakan dan bagaimana cara mengerjakannya. Kinerja merupakan hasil pekerjaan yang telah disusun (Maddeppungeng, 2017) Perlu diketahui bahwa faktor penentu yang di identifikasi untuk kinerja perusahaan adalah kinerja profitabilitas, kinerja pertumbuhan, kinerja nilai pasar, kepuasan pelanggan, kepuasan karyawan, kinerja lingkungan, kinerja audit lingkungan, kinerja tata kelola perusahaan dan kinerja sosial. (Selvam, Gayathri, Vasanth, Lingaraja, \& Marxiaoli, 2016).

Beberapa studi terkait supply chain 
management yang telah menghubungkan logistik dengan kegiatan langsung untuk menciptakan, mempertahankan dan mencapai keunggulan kompetitif atau meningkatkan kinerja perusahaan tanpa mempertimbangkan ukuran perantara untuk mencapai hasil kegiatan supply chain (Cook et al., 2011; Li et al., 2006) dalam (Al-Shboul, 2017).

Berdasarkan pada latar belakang teoritis, peneliti menyarankan delivery dependability memediasi hubungan antara elemen utama infrastructure framework dan supply chain agility untuk meningkatkan kinerja perusahaan. Oleh karena itu, menggunakan mode high delivery dependability dan menawarkan infrastructure framework terstruktur dan terkonsep dengan baik dengan elemen utama yang akan memfasilitasi kelancaran arus produk dan barang dalam supply chain hingga mencapai titik konsumsi.

Dari penelitian terdahulu diketahui bahwa Supply Chain Agility adalah sesuatu hal yang dicapai dengan menawarkan fleksibilitas yang diperlukan dengan tingkatan tinggi serta respon kecepatan dalam seluruh supply chain, hubungan antara elemen utama infrastructure framework dan supply chain agility dimediasi dengan mengirimkan produk ke pasar dengan cepat. Maka sesuai dengan landasan teori yang telah dipaparkan peneliti ini akan meneliti pengaruh penerapan Supply Chain Management terhadap keunggulan daya bersaing Competitive Advantage. Supply Chain Management yang terdiri dari Infrastructure Framework, Delivery Dependability, Time to Market, dan Supply Chain Agility sementara variabel terikat adalah Competitive Advantages terdiri dari Manufacturing Firm Performance (Al-Shboul, 2017).

Model penelitian ini mengadopsi dari penelitian terdahulu (Al-Shboul, 2017) seperti pada Gambar 1. Perbedaan penelitian ini dengan penelitian sebelumnya adalah Teknik analisis data yang digunakan dan adanya penambahan hipotesis dalam penelitian.

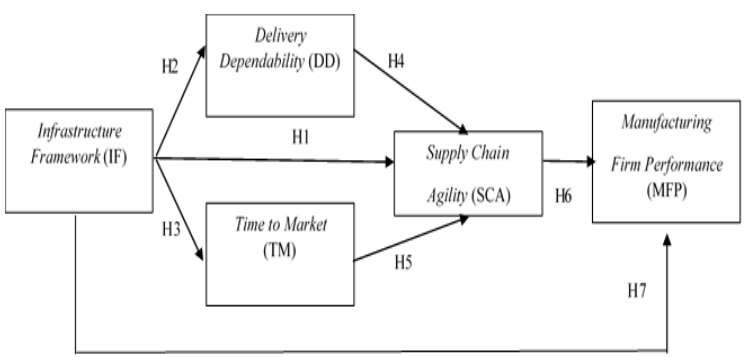

Sumber: (Al-Shboul, 2017)

Gambar 1. Model Penelitian dan Hipotesis

Dari penelitian terhadulu (Al-Shboul, 2017) menjelaskan karena kurangnya bukti empiris dalam literatur Supply Chain Management yang menunjukan bahwa hubungan antara faktor infrastructure framework dan Supply Chain Agility merupakan hambatan dalam pelaksanaan Supply Chain Management. Berdasarkan pada Gambar 2, hipotesis dalam penelitian ini adalah:

1. $\mathrm{H}_{\mathrm{I}}$ : Faktor Infrastructure Framework (IF) ke Supply Chain Agility (SCA) berpengaruh signifikan dan positif terhadap Competitive Advantage.

2. $\mathrm{H}_{2}$ : Faktor Infrastructure Framework (IF) ke Delivery Dependability (DD) berpengaruh signifikan dan positif terhadap Competitive Advantage.

3. $\mathrm{H}_{3}$ : Faktor Infrastructure Framework (IF) ke Time to Market (TM) berpengaruh signifikan dan positif terhadap Competitive Advantage.

4. $\mathrm{H}_{4}$ : Faktor Delivery Dependability (DD) ke Supply Chain Agility (SCA) berpengaruh signifikan dan positif terhadap Competitive Advantage.

5. $\mathrm{H}_{5}$ : Faktor Time to Market (TM) ke Supply Chain Agility (SCA) berpengaruh signifikan dan positif terhadap Competitive Advantage.

6. $\mathrm{H}_{6}$ : Faktor Supply Chain Agility (SCA) berpengaruh signifikan dan positif terhadap Competitive Advantage.

7. $\mathrm{H}_{7}$ : Faktor Infrastructure Framework (IF) berpengaruh signifikan dan positif terhadap Competitive Advantage.

\section{METODE PENELITIAN}

Dalam penelitian ini, penulis menggunakan metode kuantitatif dan eksplanatori dengan pendekatan causal. Hal ini dikarenakan adanya variabel-variabel yang akan ditelaah hubungannya serta tujuannya untuk menyajikan gambaran mengenai hubungan antara variabel-variabel yang diteliti.

Terdapat dua variabel dalam penelitian ini yaitu Supply Chain Management dengan beberapa dimensi seperti Infrastructure Framework (IF), Delivery Dependability (DD), Time to Market (TM), dan Supply Chain Agility (SCA). Sedangkan pada variabel Competitive Advantage dengan satu dimensi yaitu Manufacturing Firm Performance (MFP).

Tabel 3. Operasional Variabel dan Pernyataan

\begin{tabular}{|c|c|l|}
\hline No & $\begin{array}{c}\text { Sub } \\
\text { Var. }\end{array}$ & \multicolumn{1}{|c|}{ Pernyataan } \\
\hline & & $\begin{array}{l}\text { Supplier kami menggunakan jalan } \\
\text { sebagai cara cepat untuk melayani } \\
\text { pesanan pelanggan (IF1). }\end{array}$ \\
\cline { 3 - 4 } 1. & $\begin{array}{c}\text { Infrastr } \\
\text { ucture } \\
\text { Framew } \\
\text { ork }\end{array}$ & $\begin{array}{l}\text { Supplier kami mengantarkan } \\
\text { sebagian besar produk ke } \\
\text { pelanggan melalui jalan karena } \\
\text { biaya yang rendah (IF2). }\end{array}$ \\
\hline
\end{tabular}




\begin{tabular}{|c|c|c|}
\hline & & $\begin{array}{l}\text { Jalur darat dianggap sebagai } \\
\text { fasilitas yang efisien untuk } \\
\text { mengirimkan produk supplier } \\
\text { (IF3). }\end{array}$ \\
\hline & & $\begin{array}{l}\text { Perusahaan kami menggunakan } \\
\text { layanan seluler dan internet untuk } \\
\text { menghubungi pemasok (IF4). }\end{array}$ \\
\hline & & $\begin{array}{l}\text { Jaringan telekomunikasi memiliki } \\
\text { ke andalan yang tinggi dalam } \\
\text { pengiriman (IF5). }\end{array}$ \\
\hline \multirow[t]{11}{*}{2.} & \multirow[t]{11}{*}{$\begin{array}{l}\text { Supply } \\
\text { Chain } \\
\text { Agility }\end{array}$} & $\begin{array}{l}\text { Supply Chain } r \text { kami } \\
\text { mempertahankan kapasitas } \\
\text { persediaan yang lebih untuk } \\
\text { merespon peningkatan/perubahan } \\
\text { pasar (SCA1). }\end{array}$ \\
\hline & & $\begin{array}{l}\text { Supply Chain kami merespon } \\
\text { dengan cepat untuk menawarkan } \\
\text { spesifikasi yang khusus kepada } \\
\text { pelanggan (SCA2). }\end{array}$ \\
\hline & & $\begin{array}{l}\text { Supply Chain kami merespon } \\
\text { dengan cepat untuk menghasilkan } \\
\text { produk yang berbeda seperti: } \\
\text { pilihan, ukuran dan rasa (SCA3). }\end{array}$ \\
\hline & & $\begin{array}{l}\text { Supply Chain kami merespon } \\
\text { dengan cepat untuk menyesuaikan } \\
\text { kapasitas (merubah produk) dalam } \\
\text { produksi sehubungan dengan } \\
\text { permintaan pelanggan yang } \\
\text { berubah dengan cepat (SCA4). }\end{array}$ \\
\hline & & $\begin{array}{lr}\begin{array}{l}\text { Supply Chain kami } \\
\text { dengan merespon } \\
\text { memperkenalkan }\end{array} & \text { untuk } \\
\text { perubahan besar pada peningkatan } \\
\text { produk (SCA5). }\end{array}$ \\
\hline & & $\begin{array}{l}\text { Supply Chain kami merespon } \\
\text { dengan cepat untuk menawarkan } \\
\text { atau memperkenalkan produk- } \\
\text { produk baru bagi pelanggan } \\
\text { (SCA6). }\end{array}$ \\
\hline & & $\begin{array}{l}\text { Supply Chain kami merespon } \\
\text { dengan cepat untuk memenuhi } \\
\text { permintaan pelanggan tepat waktu } \\
\text { tanpa penundaan (SCA7). }\end{array}$ \\
\hline & & $\begin{array}{l}\text { Supply Chain kami merespon } \\
\text { dengan cepat } \\
\text { memperkenalkan banyak inovasi } \\
\text { dan variasi produk (SCA8). }\end{array}$ \\
\hline & & $\begin{array}{l}\text { Supply Chain kami } \\
\text { secara efektif terhadap perubahan } \\
\text { kebutuhan biaya oprasional } \\
\text { (SCA9). }\end{array}$ \\
\hline & & $\begin{array}{l}\text { Supply Chain kami merespon } \\
\text { secara efektif terhadap perubahan } \\
\text { kebutuhan produk (SCA10). }\end{array}$ \\
\hline & & $\begin{array}{l}\text { Kustomisasi produk kami dengan } \\
\text { menambahkan sedikit pembaruan } \\
\text { (SCA11). }\end{array}$ \\
\hline \multirow[t]{3}{*}{3} & \multirow{3}{*}{$\begin{array}{l}\text { Deliver } \\
y \\
\text { Depend } \\
\text { ability }\end{array}$} & $\begin{array}{l}\text { Supplier kami memberikan jenis } \\
\text { produk yang dibutuhkan dalam } \\
\text { kondisi yang tepat (DD1). }\end{array}$ \\
\hline & & $\begin{array}{l}\text { Supplier kami mengirimkan } \\
\text { pesanan pelanggan tepat waktu } \\
\text { tanpa penundaan (DD2). }\end{array}$ \\
\hline & & $\begin{array}{l}\text { Supplier kami sering memperbarui } \\
\text { mode pengiriman (DD3). }\end{array}$ \\
\hline
\end{tabular}

\begin{tabular}{|c|c|c|}
\hline & & $\begin{array}{l}\text { Supplier kami menyediakan } \\
\text { pengiriman yang sangat andal dan } \\
\text { efesien (DD4). }\end{array}$ \\
\hline \multirow[t]{4}{*}{4.} & \multirow[t]{4}{*}{$\begin{array}{l}\text { Time to } \\
\text { Market }\end{array}$} & $\begin{array}{l}\text { Supplier kami dapat mengirimkan } \\
\text { berbagai jenis produk ke pasar } \\
\text { dengan cepat (TM1). }\end{array}$ \\
\hline & & $\begin{array}{l}\text { Supplier kami } \text { memiliki } \\
\text { kemampuan untuk mengirimkan } \\
\text { pesanan pelanggan khusus dengan } \\
\text { cepat (TM2). }\end{array}$ \\
\hline & & $\begin{array}{l}\text { Supplier kami memiliki } \\
\text { pengembangan produk yang cepat } \\
\text { (TM3). }\end{array}$ \\
\hline & & $\begin{array}{l}\text { Supplier kami memiliki waktu } \\
\text { drop ke pasar yang lebih cepat } \\
\text { daripada rata-rata industri lain } \\
\text { (TM4). }\end{array}$ \\
\hline \multirow[t]{7}{*}{5.} & \multirow{7}{*}{$\begin{array}{l}\text { Manufa } \\
\text { cturing } \\
\text { Firm } \\
\text { Perform } \\
\text { ance }\end{array}$} & Nilai saham (MFP1). \\
\hline & & Pengembalian Investasi (MFP2). \\
\hline & & $\begin{array}{l}\text { Pertumbuhan pangsa pasar } \\
\text { (MFP3). }\end{array}$ \\
\hline & & Peningkatan penjualan (MFP4). \\
\hline & & $\begin{array}{l}\text { Peningkatan laba atas investasi } \\
\text { (MFP5). }\end{array}$ \\
\hline & & $\begin{array}{l}\text { Marjin keuntungan dan penjualan } \\
\text { (MFP6). }\end{array}$ \\
\hline & & $\begin{array}{l}\begin{array}{l}\text { Posisi kompetitif keseluruhan } \\
\text { (MFP7). }\end{array} \\
\end{array}$ \\
\hline
\end{tabular}

Sumber: (Al-Shboul, 2017)

Populasi dalam penelitian ini adalah Owner, Manajer Logistik, Manajer Penjualan, Manajer Keuangan dan Barista, di kedai 911 Coffee Lab, Mobelab, Teorema Coffee, Suarasa Coffee, dan Bicara Street Coffee. Sedangkan sampel dalam penelitian adalah sampel jenuh. Menurut Sugiyono dalam (Endra, 2017) sampel jenuh adalah teknik penentuan sampel bila semua anggota populasi digunakan sebagai sampel. Hal ini sering dilakukan bila jumlah populasi relatif kecil, kurang dari 30 orang, atau peneliti yang ingin membuat generalisasi dengan kesalahan yang sangat kecil. Istilah lain sampel jenuh adalah sensus, dimana semua anggota populasi dijadikan sampel. Dalam penelitian ini yang menjadi sampel adalah 30 responden yang terdiri dari Owner, Manajer Logistik, Manajer Penjualan, Manajer Keuangan dan Barista.

Pengumpulan data dilakukan melalui kuesioner atau angket serta wawancara untuk mendapatkan data primer dari objek yang diteliti.

Peneliti menggunakan uji validitas dan reliabilitas. Uji validitas dilakukan untuk mengukur sah atau tidaknya indikator atau kuesioner dari masing-masing variabel. Pengujian dilakukan dengan membandingkan nilai hitung dan tabel (Simamora, 2017). Uji reliabilitas dilakukan secara bersama-sama terhadap seluruh pernyataan (Mariadi, 2017). Uji reliabilitas digunakan untuk mengetahui konsistensi alat ukur, apakah alat pengukur yang digunakan dapat diandalkan dan tetap konsisten jika pengukuran 
tersebut diulang (Dewi, 2018)

Teknik analisis data dalam penelitian menggunakan analisis multivariate. Terdapat tiga jenis teknik dalam analisis multivariate, yaitu: (1). Teknik dependent, (2). Teknik interdependent, dan (3). Teknik persamaan structural (structural model). Teknik dependent yaitu jika variabel dependen dipengaruhi oleh variabel independen. Sedangkan teknik interdependent yaitu jika semua variabel saling berpengaruh. Dengan kata lain, dalam teknik interdependen semua variabel adalah independen. Sedangkan teknik structural model atau Structural Equation Modeling (SEM) menganalisis variabel dependen dan independen secara simultan (Haryono, 2017).

\section{Structural Equation Modeling (SEM)}

Tenik Analisis Structural Equation Modeling (SEM) adalah sebagai perluasan atau kombinasi analisis dari beberapa tehnik analisis multivariat, merupakan jawaban dari analisis terintegras, Structural Equation Modeling (SEM) juga mempunyai karakteristik yang berbeda dengan regresi biasa (Arisena, 2016) Sedangkan menurut Chin dalam (Wiyono, 2017), Structural Equation Modeling (SEM) adalah salah satu kajian bidang statistika yang dapat digunakan untuk mengatasi masalah penelitian, dimana peubah bebas maupun peubah respon adalah peubah yang tak terukur. Terdapat dua model persamaan struktural yaitu Structural Equation Modeling (SEM) berdasarkan pada covariance (CBSEM) dan Structural Equation Modeling (SEM) berbasis component Partial Least Square (PLS).

\section{Partial Least Square (PLS)}

Partial Least Square (PLS) adalah distribution free yang artinya data tidak bersyaratkan berdistribusi tertentu, dapat berupa nominal, kategori, ordinal, interval dan rasio. Partial Least Square (PLS) merupakan tehnik yang kuat dalam menganalisis variabel laten yang memiliki beberapa indikator pada Structural Equation Modeling (SEM). Chin Partial Least Square (PLS) menggunakan prosedur estimasi berbasis minimum squares, dimana tidak memiliki tekanan pada skala pengukuran, distribusi data ataupun ukuran sampel. Dapat disimpulkan bahwa Partial Least Square (PLS) adalah sebuah pendekatan alternatif yang bergeser dari pendekatan Structural Equation Modeling (SEM) berbasis covariance menjadi berbasis variance (Hadi \& Hidayati, 2018).

\section{Metode Trimming}

Model Trimming adalah model yang digunakan untuk memperbaiki suatu model struktur analisis jalur dengan cara mengeluarkan variabel eksogen yang koefisien jalurnya tidak signifikan (Adiningrum, Dwiyana, \& Lestari, 2018). Jadi, model trimming terjadi ketika koefisien jalur diuji secara keseluruhan ternyata ada variabel yang tidak signifikan, peneliti perlu memperbaiki model struktur analisis jalur yang sudah dihipotesiskan. Cara menggunakan metode trimming yaitu menghitung ulang koefisien jalur tanpa menyertakan variabel eksogen yang koefisien jalurnya tidak signifikan.

\section{HASIL DAN PEMBAHASAN}

\section{Model Konstruk}

Berdasarkan data-data yang telah diolah menggunakan software SmartPLS 3.0, maka model konstruk penelitian ini dapat ditampilkan pada Gambar 2.

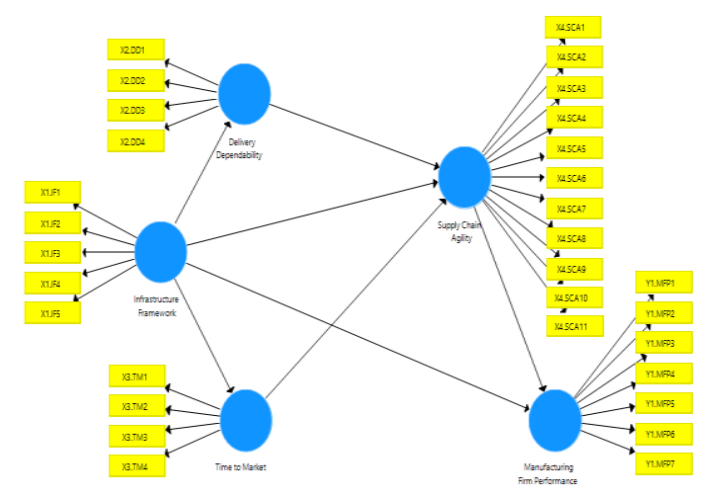

Sumber: Hasil Pengolahan Data Penulis, 2020 Gambar 2. Hasil Konstruk PLS

\section{Evaluasi Outer Model}

Evaluasi outer model bertujuan untuk mengevaluasi variabel indikator. Evaluasi outer model dilakukan setelah operasionalisasi PLS algorithm. Secara umum variabel indikator dipertahankan apabila koefisien $\geq 0,5$. Indikator yang mempunyai nilai outer loading $\geq 0.5$ maka akan dilanjutkan pada tahap PLS bootstrapping (Suhadak, 2019).

\section{a. Convergent Validity}

Untuk menguji convergent validity digunakan nilai outer loading atau loading factor. Suatu indikator dinyatakan memenuhi convergent validity secara umum dalam kategori baik apabila nilai outer loading > 0,5. Dari hasil outer loading terdapat 8 (delapan) item pernyataan yang mempunyai outer loading $<0,5$ artinya indikator tersebut dinyatakan tidak valid. Item yang tidak valid tersebut adalah item pernyataan dengan kode IF4, IF5, DD3, TM3, SCA3, SCA11, MFP1, dan MFP7. Maka model persamaan substruktur perlu di-perbaiki melalui metode Trimming. Setelah dilakukan Trimming terhadap pernyataan yang tidak valid, semua indikator memiliki nilai outer loading > 0,7. yang dianggap cukup untuk memenuhi syarat convergent validity.

Berdasarkan pendapat Noor (2014:149) dalam (Rahmayani, 2019) nilai AVE direkomendasikan lebih besar dari 0,5. Selain itu, 
pengujian dengan communality juga dilakukan, communality adalah ukuran kualitas model pada setiap variabel laten yang dihasilkan dalam PLS. Hasil dari nilai AVE untuk semua variabel diperoleh nilai AVE kurang dari 0,5 yang dinyatakan bahwa semua variabel tidak valid. Oleh karena itu, penulis akan melakukan metode trimming untuk memperbaiki variabel yang tidak valid. Tabel hasil trimming semua variabel seperti pada tabel 4.

Tabel 4. Nilai Trimming AVE

\begin{tabular}{|c|c|}
\hline Variabel & Nilai AVE \\
\hline Delivery Dependability & 0.550 \\
\hline Infrastructure Framework & 0.746 \\
\hline $\begin{array}{c}\text { Manufacturing Firm } \\
\text { Performance }\end{array}$ & 0.588 \\
\hline Supply Chain Agility & 0.563 \\
\hline Time to Market & 0.502 \\
\hline
\end{tabular}

Sumber: Pengolahan Data Peneliti, 2020

Berdasarkan hasil pengolahan kembali dengan metode trimming, semua variabel pada tabel 4 dinyatakan valid dengan nilai skor $>0,5$.

\section{b. Dicsriminant Validity}

Menurut Ghozali (2015) dalam (Sudibyo, Bakhtiar, \& Hasanah, 2019) bahwa nilai outer loading dapat ditoleransi untuk diikutkan dalam model yang masih dalam tahap pengembangan hingga nilai 0,50 dan jika dibawah nilai 0,50 maka dapat dihapuskan dari analisis. Dari hasil olah data, ada beberapa nilai cross loading yang kurang dari 0,7 sehingga dilakukan trimming. Setelah dilakukan trimming nilai cross loading setiap variabel menunjukkan nilai $>0,7$ yang dinyatakan valid.

Uji discriminant validity juga dapat dievaluasi melalui nilai Fornel-Larcker Criterion dengan indikator dari pengukur suatu konstruk berkolerasi tinggi dengan konstruk itu sendiri dan berkolerasi rendah dengan indikator konstruk lainnya. Sehingga dapat disimpulkan bahwa korelasi antar variabel laten memenuhi kriteria validitas diskriminan, sehingga konstruk ini dinyatakan valid (Ghozali \& Latan, 2015:77) dalam (Rahmayani, 2019). Dalam pengukuran ini penulis tidak melakukan perbaikan dengan metode trimming dikarenakan variabel sudah dinyatakan valid.

Terlebih daripada itu, pengujian discriminant validity pada penelitian ini menggunakan heterotraitmonotrait ratio of correlations (HTMT) dengan indikator semua hasil nilai tidak $>0.9$. Jika nilai tidak $>0,9$ penelitian ini telah memenuhi semua kriteria terkait dengan pengujian measurement model (Rosita \& Sosianika, 2019). Dari hasil olah data, nilai HTMT masih ada yang > 0,9 oleh karena itu, dilakukan trimming. Setelah dilakukan trimming masih ada 1 indikator yang nilainya > 0,9 yang artinya variabel tersebut kurang berpengaruh secara signifikan.

\section{c. Uji Reliabilitas}

Didasari bahwa penelitian ini menggunakan skala pengukuran melalui likert scale, maka metode reliability test yang digunakan adalah Cronbach alpha. Composite Reliability memiliki syarat besaran Cronbach's Alpha nilai lebih dari 0,5 maka data tersebut reliabel (Haribowo, 2017) dalam (Sudibyo, Bakhtiar, \& Hasanah, 2019). Sedangkan syarat nilai Composite Realibity minimal 0,70 sedang idealnya ialah 0,80 atau 0,90 (Ghozali, 2015) dalam (Sudibyo, Bakhtiar, \& Hasanah, 2019).

Tabel 5. Hasil Uji Composite Reliability dan Cronbach's Alpha

\begin{tabular}{|c|c|c|}
\hline Variabel & $\begin{array}{c}\text { Composite } \\
\text { Rreliability }\end{array}$ & $\begin{array}{c}\text { Cronbach's } \\
\text { Alpha }\end{array}$ \\
\hline DD & 0,639 & 0,662 \\
\hline IF & 0,810 & 0,774 \\
\hline MFP & 0,834 & 0,764 \\
\hline SCA & 0,869 & 0,828 \\
\hline TM & 0,710 & 0,654 \\
\hline
\end{tabular}

Sumber: Hasil Pengolahan Data Peneliti, 2020

Tabel 5 menunjukkan bahwa variabel laten Delivery Dependability memiliki nilai Cronbach's Alpha dan Composite Reliability < 0,7, sedangkan untuk variabel Time to Market dan Delivery Dependability hanya di bagian uji Cronbach's Alpha yang memiliki nilai < 0,7 . Sehingga hasil tersebut dapat disimpulkan bahwa keseluruh variabel adalah reliabel, jadi tidak perlu melakukan metode trimming.

\section{Pengajuan Inner Model}

Uji Inner Model digunakan untuk mengevaluasi hubungan antar konstruk laten seperti yang telah dihipotesiskan dalam penelitian. Ghozali dan Latan (2015:81) dalam (Rahmayani, 2019) juga menjelaskan Rule of Thumb inner model dimana $\mathrm{R}$ square yang bernilai 0,75 menggambarkan nilai yang kuat, nilai 0,5 artinya moderate, dan $\mathrm{R}$ square 0,25 untuk model yang lemah. Sedangkan Q2 > 0 menunjukkan model yang predictive relevance. Tabel 6 menujukkan hasil perhitungan R-Square.

Tabel 6. Hasil R-Square

\begin{tabular}{|c|c|c|}
\hline Variabel & R Square & Keterangan \\
\hline Delivery Dependability & 0,157 & Lemah \\
\hline $\begin{array}{c}\text { Manufacturing Firm } \\
\text { Performance }\end{array}$ & 0,450 & Moderat \\
\hline Supply Chain Agility & 0,579 & Moderat \\
\hline Time to Market & 0,308 & Moderat \\
\hline
\end{tabular}

Sumber: Hasil Pengolahan Data Penulis, 2020

Tabel 6 menunjukkan hasil $\mathrm{R}$ square dari variabel Delivery Dependability sebesar 0,157 atau 15,7\% yang berarti Delivery Dependability memiliki 
model yang lemah, sedangkan variabel Manufacturing Firm Performance memiliki skor 0,450 atau 45,0\%, Supply Chain Agility memiliki skor 0,579 atau $57,9 \%$, dan Time to Market memiliki skor 0,308 atau $30,8 \%$ yang berarti memiliki model dengan kekuatan moderate untuk mengukur konstruk.

Tabel 7. Hasil Q- Square

\begin{tabular}{|c|c|c|}
\hline Variabel & Q Square & Keterangan \\
\hline Delivery Dependability & 0.033 & Lemah \\
\hline $\begin{array}{c}\text { Manufacturing Firm } \\
\text { Performance }\end{array}$ & 0.134 & Lemah \\
\hline Supply Chain Agility & 0.179 & Moderat \\
\hline Time to Market & 0.060 & Lemah \\
\hline
\end{tabular}

Sumber: Hasil Pengolahan Data Peneliti, 2020

Tabel 7 menunjukkan hasil $\mathrm{Q}^{2}$ dari Delivery Dependability sebesar 0.033, Manufacturing Firm Performance sebesar 0.134, Supply Chain Agility sebesar 0.179, Time to Market sebesar 0.060 . Menurut Ghozali dan Latan (2015:81) dalam (Rahmayani, 2019) nilai Q-square 0,02 berarti predictive relevance lemah, 0,15 berarti predictive relevance moderat, dan 0,35 predictive relevance kuat.

\section{Uji Hipotesis}

Pengukuran efek mediasi adalah jika nilai $T$ statistic $>1,64$ dengan signifikan 5\% untuk hipotesis one tailed berarti variabel memediasi penuh (fully mediating), sehingga hipotesis untuk efek mediasi terdukung (Abdillah \& Hartono, 2015:233) dalam (Rahmayani, 2019). Setelah dilakukan Uji T-statistic dari boostrapping menggunakan SmartPLS 3.0 terdapat tiga hipotesis mediasi yang ditolak, yaitu hubungan variabel Infractructure Framework terhadap Manufacturing Firm Performance, Infractructure Framework terhadap Supply Chain Agility, dan Time to Market terhadap Supply Chain Agility ditolak karena nilai T-statistic $<1,64$. Maka penulis akan melakukan penghitungan ulang dengan metode trimming untuk memperbaiki faktor pengaruh, barang kali ada kemungkinan nilai $t$ statistic yang bertambah. Hasil pengolahan dengan metode trimming bisa dilihat pada tabel berikut:

Tabel 8. Hasil Trimming Uji Hipotesis

\begin{tabular}{|c|c|c|c|c|}
\hline $\begin{array}{c}\text { Hubungan } \\
\text { Variabel }\end{array}$ & $\begin{array}{c}\boldsymbol{T} \text { - } \\
\text { Statistics }\end{array}$ & $\begin{array}{c}\text { Original } \\
\text { Sample } \\
(\mathbf{O})\end{array}$ & $\begin{array}{c}\boldsymbol{P} \\
\text { Values }\end{array}$ & Ket. \\
\hline $\begin{array}{c}\text { DD } \rightarrow \\
\text { SCA }\end{array}$ & 3,057 & 0,517 & 0,002 & Diterima \\
\hline $\mathrm{IF} \rightarrow \mathrm{DD}$ & 2,437 & 0,396 & 0,015 & Diterima \\
\hline $\mathrm{IF} \rightarrow \mathrm{MFP}$ & 0,730 & 0,027 & 0,446 & Ditolak \\
\hline $\mathrm{IF} \rightarrow \mathrm{SCA}$ & 0,746 & 0,142 & 0,456 & Ditolak \\
\hline $\mathrm{IF} \rightarrow \mathrm{TM}$ & 3,448 & 0,555 & 0,001 & Diterima \\
\hline $\begin{array}{c}\text { SCA } \rightarrow \\
\text { MFP }\end{array}$ & 2,507 & 0,657 & 0,012 & Diterima \\
\hline
\end{tabular}

\begin{tabular}{|c|c|c|c|c|}
\hline $\begin{array}{c}\text { Hubungan } \\
\text { Variabel }\end{array}$ & $\begin{array}{c}\boldsymbol{T} \text { - } \\
\text { Statistics }\end{array}$ & $\begin{array}{c}\text { Original } \\
\text { Sample } \\
(\mathbf{O})\end{array}$ & $\begin{array}{c}\boldsymbol{P} \\
\text { Values }\end{array}$ & Ket. \\
\hline $\begin{array}{c}\text { TM } \rightarrow \\
\text { SCA }\end{array}$ & 0,562 & 0,243 & 0,574 & Ditolak \\
\hline
\end{tabular}

Sumber: Hasil Pengolahan Data Peneliti, 2020

Dari hasil pengolahan kembali menggunakan metode trimming ternyata hubungan antara variabel dinyatakan sama, akan tetapi berbeda dalam nilai skor tiap variabel.

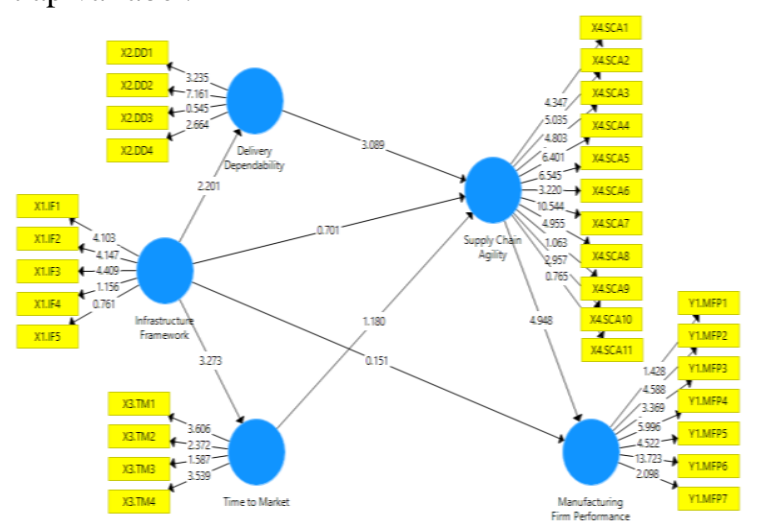

Sumber: Hasil Pengolahan Data Peneliti, 2020

Gambar 3. Hasil Boostrapping

Gambar 3 merupakan hasil Boostrapping one tailed yang diolah menggunakan SmartPLS 3.0 yang menghasilkan hubungan konstruk dan nilai T-test.

Pembahasan dari penelitian ini adalah untuk mengetahui pengaruh Supply Chain Management yang terdiri dari Infrastructure Framework, Delivery Dependability, Time to Market, dan Supply Chain Agility terhadap Manufacturing Firm Performance atau Competitive Advantage di Kedai Coffee Shop Kota Bandung bagian Selatan meliputi Kecamatan Bandung Kidul dan Lengkong. Penelitian ini mereplikasi atau mengadopsi dari penelitian sebelumnya yang dilakukan oleh (Al-Shboul, 2017) dengan judul "Infrastructure framework and manufacturing supply chain agility: the role of delivery dependability and time to market" di German-Jordanian University, Amman, Jordan. Penelitian ini menggunakan variabel yang sama dengan (Al-Shboul, 2017) yang terdiri dari Infrastructure Framework, Delivery Dependability, Time to Market, Supply Chain Agility, dan Manufacturing Firm Performance.

Pembahasan yang ada dalam penelitian dilakukan untuk melihat setiap langkah, hasil, dan analisis yang sebelumnya telah dilakukan. Langkah pengumpulan data dan informasi yang terkait dengan penelitian ini adalah dengan cara memberi kuesioner kepada 30 responden pegawai/karyawan pada 5 kedai coffee shop. 
Setelah data didapatkan baik berupa fakta maupun fenomena yang terkait dengan penelitian, data tersebut disusun yang selanjutnya membentuk urutan latar belakang dari penelitian ini. Dalam uji analisis dengan PLS, yang hasilnya akan digunakan untuk mengetahui pengaruh diterima atau tidak diterimanya sebuah hubungan. Penilaian kuesioner dilakukan dengan menggunakan skala yang masingmasing skala nya memiliki nilai tersendiri.

Berdasarkan hasil pengolahan data menggunakan PLS, terlihat bahwa hasil pengaruh Infrastructure Framework terhadap Supply Chain Agility, Time to Market terhadap Supply Chain Agility, dan Infrastructure Framework terhadap Manufacturing Firm Performance dinilai kurang berpengaruh positif signifikan dikarenakan nilai tstatistics kurang dari 1,64.

\section{KESIMPULAN}

Berdasarkan hasil analisis dan pengujian statistik yang telah dilakukan dalam penelitian ini, dapat disimpulkan beberapa hal mengenai pengaruh Infrastructure Framework, Delivery Dependability, Time to Market, dan Supply Chain Agility terhadap Manufacturing Firm Performance (Competitive Advantage). Adalah sebagai berikut:

1. Terdapat hubungan yang kurang berpengaruh secara signifikan antara variabel Infrastructure Framework (IF) ke Supply Chain Agility (SCA) terhadap Competitive Advantage.

2. Terdapat hubungan yang berpengaruh positif antara variabel Infrastructure Framework (IF) ke Delivery Dependability (DD) terhadap Competitive Advantage.

3. Terdapat hubungan yang berpengaruh positif antara variabel Infrastructure Framework (IF) ke Time to Market (TM) terhadap Competitive Advantage.

4. Terdapat hubungan yang berpengaruh positif antara variabel Delivery Dependability (DD) ke Supply Chain Agility (SCA) terhadap Competitive Advantage.

5. Terdapat hubungan yang kurang berpengaruh secara signifikan antara variabel Time to Market (TM) ke Supply Chain Agility (SCA) terhadap Competitive Advantage.

6. Terdapat hubungan yang signifikan dan berpengaruh positif antara variabel Supply Chain Agility (SCA) terhadap Competitive Advantage.

7. Terdapat hubungan yang kurang berpengaruh secara signifikan antara variabel Infrastructure Framework (IF) terhadap Competitive Advantage.
Saran bagi perusahaan yang dapat diberikan oleh penulis antara lain adalah kedai Coffee Shop dapat lebih memperhatikan faktor-faktor yang mendukung keunggulan dalam bersaing, salah satunya faktor Supply Chain Agility yang memiliki presentase nilai $t$-statistic dan original sample yang tinggi yaitu 4,948 dan 0,657. Selain itu owner dari tiap kedai coffee shop juga harus memperhatikan supplier bean mana yang tepat, agar waktu pengiriman lebih efisien dan kualitas produk yang maksimal, serta dapat menjadi pilihan supplier untuk jangka panjang (long term) hal ini juga sangat berkesinambungan dengan point Supply Chain Agility.

Diharapkan dengan hasil penelitian ini dapat menjadi tambahan pengetahuan maupun referensi bagi penelitian selanjutnya., dan juga agar hasil perhitungan prioritas dalam penelitian ini dapat dimanfaatkan bagi penyusunan penelitian berikutnya karena dalam penelitian ini sudah diketahui aspek mana yang memiliki variabel prioritas tertinggi dalam evaluasi penerapan pengaruh Supply Chain Management terhadap Competitive Advantage pengembangan supplier.

\section{REFERENSI}

Achlaq, M. M. (2015). Perancangan Produk Baru dalam Prespektif Supply Chain Management.

Adiningrum, Y.;Dwiyana;\& Lestari, T. E. (2018). Analisis Jalur Model Trimming Untuk Mengetahui Faktor Faktor Yang Mempengaruhi Motivasi Belajar Terhadap Prestasi Akademik Mahasiswa (Studi Kasus Mahasiswa Jurusan Matematika FMIPA UM).

Aisy, D. H. (2019). Analisis Pengaruh Customer Sensitivity Dan Sourcing Fexibility Terhadap Supply Chain Agility Dan Kinerja Perusahaan.

Alhamid, T., \& Anufia, B. (2019). Instrumen Pengumpulan Data.

Al-Shboul, M. A. (2017). Infrastructure Framework and Manufacturing Supply Chain Agility: the role of delivery dependability and time to market. Supply Chain Management: An International Journal.

Arisena, G. M. (2016). Konsep Kewirausahaan Pada Petani Melalui Pendekatan Structural Equation Model (SEM). E-Jurnal Agribisnis dan Agrowisata.

Dewi, D. A. (2018). Uji Validitas dan Reliabilitas. Endra, F. (2017). Metodologi Penelitian (Statistika Praktis). Taman Sidoarjo: Zifatama Jawara.

GoogleMaps. (2019). Perguruan Tinggi di Bandung Kidul dan Kecamatan Lengkong. Noudettu osoitteesta https://www.google.com/maps/search/perg 
uruan+tinggi+di+bandung+kidul+dan+leng kong/@_

$6.9370554,107.6064024,14 \mathrm{z} / \mathrm{data}=! 3 \mathrm{~m} 1 ! 4 \mathrm{~b}$ 1.

Hadi, S.;\& Hidayati, I. M. (2018). Faktor-Faktor Yang Mempengaruhi Indeks Prestasi Dosen Dengan Sem-Pls (Studi Kasus Jurusan Pendidikan Matematika Dan Teknik Elektro PTS di Surabaya).

Haryono, S. (2017). Metode SEM Untuk Penelitian Manajemen : Amos, Lisrel \& PLS.

Ifle, T. M. (2. July 2017). Pentingnya Menciptakan Competitive Advantages Dalam Perusahaan. Noudettu osoitteesta https://www.tommcifle.com/pentingnyamenciptakan-competitive-advantages/

Kementrian Perindustrian Republik Indonesia. (18. Februari 2019). Industri Makanan dan Minuman Jadi Sektor Kampiun. Noudettu osoitteesta Kementrian Perindustrian Republik Indonesia Website: https://kemenperin.go.id/artikel/20298/Indu stri-Makanan-dan-Minuman-Jadi-SektorKampiun-

Maddeppungeng, A. (2017). Pengaruh Manajemen Rantai Pasok (Mrp) Pada Daya Saing Dan Kinerja Perusahaan Jasa Konstruksi Di Dki-Jakarta.

Mariadi, A. (2017). Pengaruh Motivasi Berprestasi dan Kompetensi dalam Kinerja Karyawan studi case di PT. TASPEN (PERSERO) Bandung.

Oseptharia, A. A. (2018). Analisis Model Bisnis Pada Armor Kopi Bandung Enggunakan Pendekatan Business Model Canvas.

Pangestu, H. (2016). PENTINGNYA SUPPLY CHAIN MANAGEMENT DALAM PROSES BISNIS.

Rahmayani, L. (2019). Faktor-Faktor Yang Mempengaruhi Customer Intention Untuk Menggunakan Layanan Mobile Payment Dana.

Rosita;\& Sosianika, A. (2019). Peran Event Sponsorship Dalam Meningkatkan Kesadaran Merek dan Minat Beli: Studi pada Brand $361^{\circ}$ di Acara Asian Games 2018.
Selvam, M.;Gayathri, J.;Vasanth, V.;Lingaraja, K.;\& Marxiaoli, S. (2016). Determinants of Firm Performance: A Subjective Model.

International Journal of Social Science Studies.

Simamora, B. (2017). Pengaruh Pelatihan Dan Pengembangan Serta Prestasi Kerjaterhadap Pengembangan Karir Pegawai Pada Dinas Bina Margadan Pengairan Kota Pematangsiantar. Journal Politeknink Bisnis Indonesia.

Sudibyo, R. P.;Bakhtiar, A.;\& Hasanah, M. A. (2019). Relationship Of The Social Economic Characteristics Of The Implementation Of The Implementation Of Agricultural Assignment Tasks In City Of Batu . Jurnal Ekonomi Pertanian dan Agribisnis.

Suhadak, U. S. (2019). Pengaruh Makroekonomi Terhadap Kinerja Indeks Harga Saham Gabungan (Ihsg) Dan Government Bonds (Studi pada Negara Indonesia Tahun 20152017). Jurnal Administrasi Bisnis.

Suharto, R.;\& Devie. (2013). Analisa Pengaruh Supply Chain Management terhadap Keunggulan Bersaing dan Kinerja Perusahaan. BUSINESS ACCOUNTING REVIEW, VOL. 1. NO 2.

Wiyono, D. (2017). Pengaruh Motivasi Belajar, Keaktifan Mahasiswa Dan Kinerja Dosen Terhadap Prestasi Belajar Mahasiswa: Pendekatan Partial Least Squares-Sem Analisys. Edusentris, Jurnal Ilmu Pendidikan dan Pengajaran.

Wulandari;Sari, R. N.;\& L, A. A. (2016). Pengaruh Supply Chain Management Terhadap Kinerja Perusahaan Melalui Keunggulan Bersaing. Jurnal Ekonomi.

Zuhriyah, D. A. (Agustus 2019). Industri Kedai Kopi Ditaksir Tumbuh 20\% Tahun 2019. Noudettu osoitteesta Ekonomi Bisnis: https://ekonomi.bisnis.com/read/20190822/ 12/1139918/industri-kedai-kopi-ditaksirtumbuh-20-tahun-ini 